\title{
Attainment of "Project Management and Finance" Graduate Attribute (GA) for Post Graduate Program in Engineering through Course Project
}

\author{
Vinayak Kulkarni ${ }^{1}$, V N Gaitonde ${ }^{2}$, R.G.Mench ${ }^{3}$ \\ 1,2,3 Department of Industrial and Production Engineering, BVB College of Engineering and Technology,Hubballi-31 \\ 1vinayak_kulkarni@bvb.edu, ${ }^{2}$ vngaitonde@bvb.edu, ${ }^{3}$ mench@bvb.edu
}

\begin{abstract}
The National Board of Accreditation (NBA) in India has specified specific graduate attributes for post graduate program in engineering. In B V B College of Engineering \& Technology, Hubballi, the Production Management PG program has made an attempt to design and conduct the course project from last two academic years in the core course "Project Management" at 1st semester level, which has been designed to address the graduate attribute 7 related to "Project Management and Finance". Based on this the program outcome for our PG program is defined as "Ability to carry feasibility study and evaluate projects considering economical and financial factors". Keeping this outcome in mind, the course project has been conducted addressing feasibility study, economical and financial factors as mentioned in attribute 7 . The students were made to work on this course project for the duration of 12 weeks, which included activities like industrial visit, literature review, preliminary study, feasibility study, facets analysis, report submission and oral presentation. The evaluation process for this course project was rubrics based consisting of two different outcome elements and related performance indicators to address particularly the graduate attribute- 7 .
\end{abstract}

\section{Vinayak Kulkarni}

Department of Industrial and Production Engineering, BVB College of Engineering and Technology,Hubballi-31 vinayak_kulkarni@bvb.edu
The work carried out by the students focuses completely on the analysis of facets of projects from marketing analysis to ecological analysis. The conduct of course project in the core course like project management really differentiates the learning of post graduate level to that of undergraduate level as more work is being carried on the analysis part during the process of course project. The percentage attainment of each outcome element addressing the attribute-7 for both the academic years i.e 2013-14 and 2014-15 has been compared.

Keywords: Graduate attributes, Project Management, Course project, Feasibility study and Facets analysis

\section{Introduction}

Project management is one time activity with a definite start and end time and hence it requires lot of efforts from the project managers with regards to analysis of the facets of project management, as the phases of projects pass on quickly and there is no time to revert back into the process. The project management is complex and therefore it is a fruitful ground for creative, spontaneous and intuitive applications of particular theories to meet the stated objectives in a constantly changing environment. [2]. Usually at the undergraduate (UG) level, the project management has been taught to the students, emphasizing mainly on different phases of the project 
management starting from project conception and initiation phase to the project closure phase [3]. However, the curriculum in the course "project management" for the post graduate (PG) students of Production Management has been designed at the higher level, involving the complete analysis of all the facets of the project management. But, it is very difficult to judge the analysis capacity of the students in the course like "project management" only through regular theory classes or seminars and hence it was been decided to conduct a course project of one credit that involves the complete analysis of the facet of the project management. The course project is being conducted from last two academic years i.e. 2013-14 and 2014-15 to address the "Project Management and Finance" Graduate Attribute (GA) laid down by National Board of Accreditation (NBA). The current paper explains the planning and execution of course project for production management PG students involving all the facets of the project management that clearly addresses the "Project Management and Finance" Graduate Attribute (GA). The paper also focuses on the evaluation process, rubrics developed, and the program outcome (PO) addressed followed by feedback from the students.

\section{Topic Covered in Course Project}

The project management phases as mentioned earlier are the basic concepts that are learnt by students at the undergraduate level. But at the post graduate level, each student needs to have an ability to carry out feasibility study and evaluate the projects considering economical and financial factors. Hence, the following topics were given to the students in the course project, which helped them to enhance their analysis capacity.

\subsection{Topic Covered in Course Project}

The important facets of project analysis are
( Market analysis
૫ Technical analysis
૫ Financial analysis
( Economical analysis and
․ Ecological analysis

Along with all analysis of facets, the feasibility study at the end of preliminary phase and final phase have to be performed. [4]
2.1.1 Expected work in each of the facets and feasibility study

( Market analysis: Here, the student has to identify the aggregate demand for the proposed product/service in future before starting the project work as an initial survey and should analyze on the market share of the project under appraisal. The students were also expected to prepare SWOT analysis addressing their strengths, weakness, opportunities and threats before the commencement of the project and then they have to use any one of the portfolio matrices mandatorily in the course project as a part of the market analysis.

u Technical analysis: Here, the student has to perform technical analysis on material input and utilities, manufacturing process/technology, plant capacity, location and site. The technical analysis should also focus on the creation of project charts, layouts and work schedules.

u Financial analysis: Here, the student has to check whether the project selected is financially viable or not? The focus during this analysis is on means of financing, cost of capital, break-even point, cash flows and levels of risks etc.

( Economic analysis: Here, the student has to analyze about the selected project based on the social cost point of view and benefits of a project, which may be often different from its monetary costs and benefits.

( Ecological analysis: Here, the student has to identify whether the project selected has some impact on the environmental issues. If yes, then should list those impacts and provide suitable solutions and suggestions to avoid or prevent the adverse effect of the project on the environment. The student should also go through some rules and regulations of government regarding environmental issues, which is required to get a no objection certificate from the governmental authorities.

In the course project, a careful feasibility study has to be conducted by each team of the students, which consists of three main phases, namely- preliminary phase, analysis phase and evaluation phase. In the preliminary phase, as it is an initial phase, the students in a team have to generate ideas and conduct initial screening and check whether the idea prima facie promising? If yes, the team has to proceed further to 
the second phase or else drop the project and rework. In the second phase, the students should perform feasibility study on all the facets of project analysis right from the market analysis to ecological analysis as explained above. After all analysis, the evaluations with regards to financial and economical factors are to be carried out to accept or reject the project based on the result obtained. Finally the funding proposal should be prepared by each team of the students, which will be helpful to start a new project. [4]

\section{The Flow and Conduct of Course Project}

The course project was planned and executed in the following sequence. Table 1 gives the course project flow details.

Table 1: Course project flow details

\begin{tabular}{|c|c|c|}
\hline $\begin{array}{l}\text { Sl. } \\
\text { no }\end{array}$ & Project Flow & Description \\
\hline 1 & $\begin{array}{l}\text { Team formation and } \\
\text { selection of topic }\end{array}$ & $\begin{array}{l}\text { Two students in a team based on the area of } \\
\text { interest in project management. The topic } \\
\text { selected should be related to project } \\
\text { management and students have to discuss } \\
\text { with course instructor regarding its } \\
\text { feasibility. }\end{array}$ \\
\hline 2. & $\begin{array}{l}\text { Industry visit and } \\
\text { literature review }\end{array}$ & $\begin{array}{l}\text { Collection of primary data related to selected } \\
\text { topic. Every team has to visit one industry } \\
\text { related to the course project work. Literature } \\
\text { review is for t he collection of secondary } \\
\text { data. The information regarding setting up of } \\
\text { different types of industries are to be learnt } \\
\text { through literature review by referring } \\
\text { different national and international journals. }\end{array}$ \\
\hline 3 & $\begin{array}{l}\text { Initial plan and } \\
\text { feasibility study }\end{array}$ & $\begin{array}{l}\text { The literatu re survey conducted along with } \\
\text { topics covered in the class room will help } \\
\text { student to take decision on the feasibility of } \\
\text { the project selected. So this work will be the } \\
\text { end of phase } 1 \text { and team has to present the } \\
\text { work to the class and then proceed further } \\
\text { with the suggestions from the course } \\
\text { instructor. }\end{array}$ \\
\hline 4 & $\begin{array}{l}\text { Facet Analysis } \\
\text { (Market analysis, } \\
\text { Technical analysis, } \\
\text { Financial analysis, } \\
\text { Economic analysis and } \\
\text { Ecological analysis) }\end{array}$ & $\begin{array}{l}\text { The following concepts/tools are to be used } \\
\text { to conduct analysis } \\
\text { a. Portfolio planning tools } \\
\text { b. SWOT analysis } \\
\text { c. Demand forecasting } \\
\text { d. Work schedule } \\
\text { e. Means of finance } \\
\text { f. Breakeven point } \\
\text { g. Projected cash flow statements and } \\
\text { balance sheets } \\
\text { h. Time value of money } \\
\text { i. Analysis of risks } \\
\text { j. social cost benefit analysis etc. }\end{array}$ \\
\hline 5 & $\begin{array}{l}\text { Report preparation, } \\
\text { submission and final } \\
\text { presentation }\end{array}$ & $\begin{array}{l}\text { Finally the report has to be prepared with all } \\
\text { data collected and analyzed. One report } \\
\text { consisting of data analysis and interpretation } \\
\text { should be submitted before the presentation }\end{array}$ \\
\hline
\end{tabular}

\subsection{Topics Selected for course project by students}

The broad level topic given to the entire class related to project management was "Preparing a funding proposal with feasibility study for setting up of new industry" preferably manufacturing industry and service industry. Table 2 shows the list of course projects carried out during the year 2014-15 in the subject project management during 12 weeks duration. The students have to visit industry to collect the primary data for the project. Table 2 illustrates the course project titles and concerned industries visited by the students. [5]

Table 2: Course Project titles and industries visited

\begin{tabular}{|c|l|l|}
\hline $\begin{array}{c}\text { Team } \\
\text { no }\end{array}$ & \multicolumn{1}{|c|}{ Course project title } & \multicolumn{1}{c|}{ Industry visited } \\
\hline 1 & $\begin{array}{l}\text { Analysis of setting up of a } \\
\text { valve industry }\end{array}$ & $\begin{array}{l}\text { Veetech Valves Pvt Ltd } \\
\text { - Hubli }\end{array}$ \\
\hline 2 & $\begin{array}{l}\text { Project analysis for sugar } \\
\text { industry }\end{array}$ & $\begin{array}{l}\text { Manali Sugar Industries, } \\
\text { Malghan Tq. Sindagi } \\
\text { Dst; Bijapur }\end{array}$ \\
\hline 3 & $\begin{array}{l}\text { Project analysis for } \\
\text { setting up a fastener } \\
\text { industry }\end{array}$ & $\begin{array}{l}\text { Fastener and Allied } \\
\text { Products Pvt Ltd. } \\
\text { Industrial Estate - Hubli }\end{array}$ \\
\hline 4 & $\begin{array}{l}\text { Case study on setting up a } \\
\text { cement industry }\end{array}$ & $\begin{array}{l}\text { J.K.Super Cement Pvt. } \\
\text { Ltd - Mudhol }\end{array}$ \\
\hline 5 & $\begin{array}{l}\text { Planning for sett ing up a } \\
\text { steel manufacturing } \\
\text { industry }\end{array}$ & $\begin{array}{l}\text { Jindal (JSW) Steel Plant } \\
\text {-Toranagallu - Bellary }\end{array}$ \\
\hline 6 & $\begin{array}{l}\text { Setting up a small scale } \\
\text { DAL industry }\end{array}$ & $\begin{array}{l}\text { Gautham Dal Industry, } \\
\text { Tarihal - Hubli }\end{array}$ \\
\hline 7 & $\begin{array}{l}\text { Plan to set up a gear } \\
\text { manufacturing industry }\end{array}$ & $\begin{array}{l}\text { Devgi Warners Pvt Ltd - } \\
\text { Sirsi }\end{array}$ \\
\hline
\end{tabular}

\section{Course Project Assessment}

As mentioned earlier, the course project was designed to address the "Project Management and Finance" Graduate Attribute (GA) laid down by National Board of Accredation (NBA) for the post graduate program in engineering. Based on the above graduate attribute, the program out come (PO) for post graduate production management has been framed as "Ability to carry feasibility study and evaluate projects considering economical and financial factors".[1]

According to this attribute, two separate outcome elements were framed and as well as related performance indicators were also identified indicators are mentioned below.

Outcome Element 1(Competency 1): Demonstrate the technical and management skills and knowledge to plan analyze and implement the projects. 
The above mentioned outcome element was supported with two performance indicators.

i. Discuss the stages in project planning through implementation

ii. Discuss the steps followed in conducting a feasibility study.

Outcome Element 2(Competency 2): Ability to carry out marketing, technical, financial, economical, and ecological analysis to evaluate the projects.

The above mentioned outcome element was supported with four performance indicators.

i. Prima-facie selection and planning of project.

ii. Carry out market, technical and financial analysis.

iii. Carry out economical and ecological analysis.

iv. Final selection and implementation of the project.

Once the performance indicators were set for each of the outcome elements, it was decided to evaluate each indicator for 20 marks. Therefore the whole course project was evaluated for 120 marks as there are six performance indicators. Finally the 120 marks have been scaled down to 25 marks. 20 marks were allotted for each of the indicators and the rubrics were designed accordingly. Each performance indicator was assessed based on the student's performance, which falls under four different categories, namely, outstanding, admirable, average or inadequate. If it is found outstanding, then the student is allotted 75$100 \%$ of the marks allocated, if the work is admirable then $50-75 \%$ of the marks allotted, if the work is average then $25-50 \%$ of the marks allotted and if the work is inadequate then based on the rubrics the student gets up to $25 \%$ of the total marks allotted.

\subsection{Attainment of GAand related outcomes}

\subsubsection{Attainment of PO for year 2013-14}

Figures 1-3 indicate the attainment of outcome element 1 and outcome element 2 along with overall the attainment of PO for the year 2013-14. There was $72 \%$ attainment of GA for the first cycle of course project conducted. The attainment of outcome element 2 was found to be good compared to outcome element 1 because students have worked more towards the analysis part related to marketing, technical and financial analysis. But still there was a lot of scope to improve the work and analysis part on ecological and economical factors. The feasibility study was found to be just above average by all the students, whereas they could have worked more on it to attain more knowledge and marks.

\section{(\% attainment of OE1)}

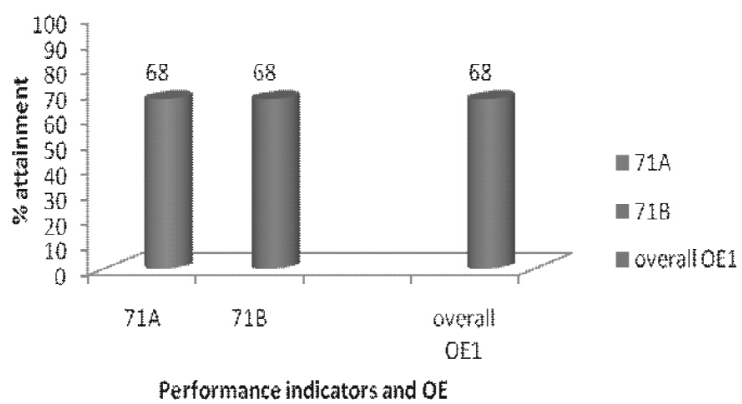

Figure 1

Outcome element 1 attainment 2013-14

\section{(\% attainment of OE2)}

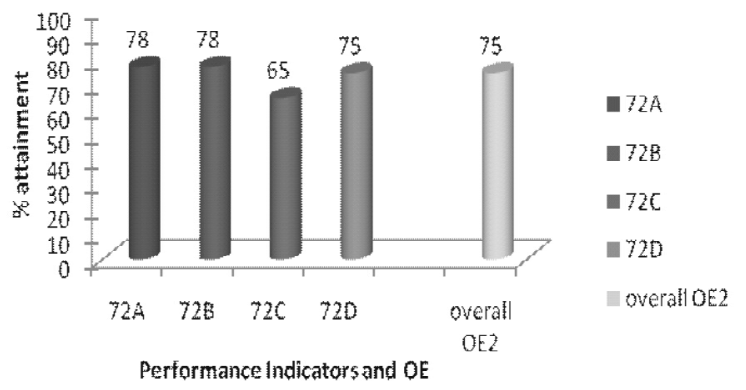

Figure 2

Outcome element 2 attainment 2013-14

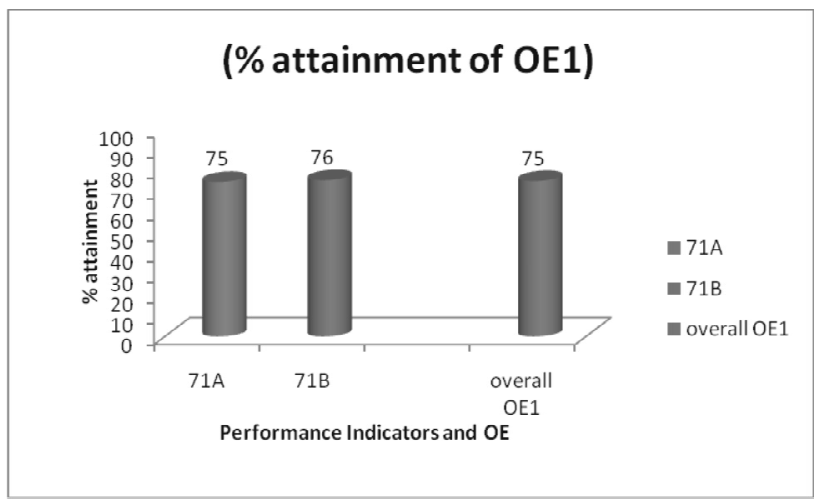

Figure 3

Attainment of graduate attribute (GA) for the year 2013-14 
The attainment of performance indicator $72 \mathrm{C}$ in chart figure no 2 was found to be low with $65 \%$ of attainment because the students did not collect sufficient information regarding the concepts of economical and ecological factors. With clear understanding of the course project process and drawbacks from this result, some modifications were made in the next cycle and even students were trained in accordance with it.

\subsubsection{Attainment of PO for year 2014-15}

Figures 4-6 indicate the attainment of outcome element 1 and outcome element 2 along with overall attainment of GA for the year 2014-15.It is clearly observed from these figures that the attainment of GA increased from $72 \%$ to $79 \%$ in the next cycle of the course project, which shows a positive development. The attainment of outcome elements 1 and 2 has increased to an extent of $5-7 \%$, because of clear understanding of the process and the students visit to industries for the collection of primary data had an impact on concepts of project management.

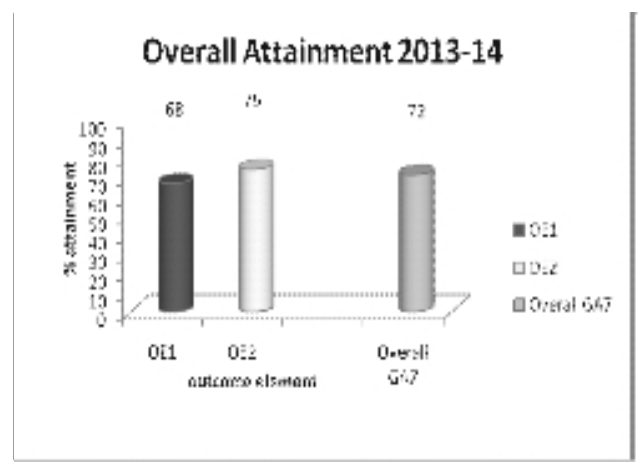

Figure 4

Outcome element 1 attainment 2014-15

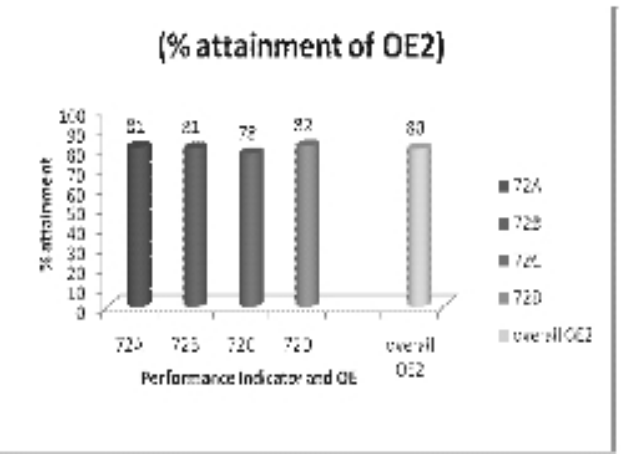

Figure 5

Outcome element 2 attainment 2014-15

\section{Overall Attainment 2014-15}

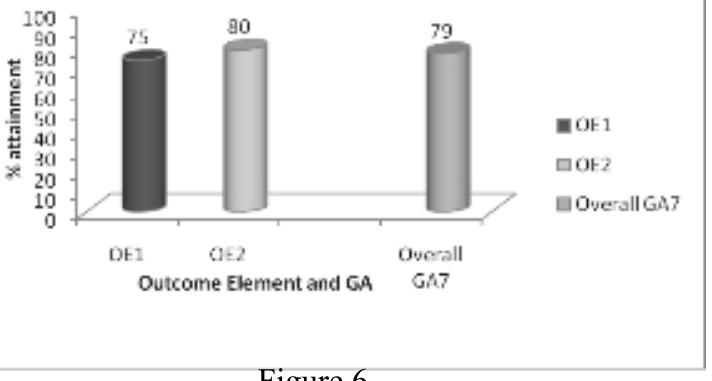

Figure 6

Attainment of graduate attribute - 7 for the year 2014-15

Through the evaluation of course project reports as well as the GA attainment (Figures 4, 5 and 6), it was observed that students have to still focus on the feasibility study in detail and the analysis of ecological and economical factors. Considerable improvement was evidenced in the marketing analysis, technical analysis and financial analysis for the year 2014-15 ie. in the second cycle of course project due to better correlation with the theoretical concepts learnt in the class room sessions. Hence, the faculty has to train students more on feasibility study and some factors of ecological and economical issues in the next cycle for the academic year 2015-16 before the conduct of course project.

\section{Case Study}

As a sample case study we would like to highlight the course work carried out by a batch of students on Project analysis for sugar industries. The work by the students started basically with the introduction to their work which threw light on the recent situation of the Indian sugar industries and scope for setting up of new sugar industry. In the literature survey part, the students categorised the work as primary and secondary information collection. As a source of primary information collection, they visited the MANALI SUGAR industry which is at Bijapur District. The secondary information was collected with the help of national and international journals. Here the students studied the trend of the sugar companies and their repective productivity in Indian context. After the literature survey, the students defined the problem definition, stated the objectives, mentioned the scope and decided to set up a fully integrated sugar industry at Mannapur village, Bijapur District in Karnataka State. Further the students mentioned the methodology of their course project and prepared a feasibility report. To study the 
feasibility of the work, an initial analysis on SWOT was performed. Looking at the results of the SWOT analysis, the further analysis on marketing, technical, financial, economical and ecological factors were conducted. Then the detail analysis of all the facets were carried out. In the facets of project analysis the following work were done by the students.

\section{Market Analysis:}

Q Information and data was collected regarding world sugar production and consumption, similarly the data was also collected on Indias sugar production and imports.

口 Collection of information on largest sugar producers and largest sugar consumers.

․ Projected demand for sugar in India upto 2016-17.

口 Information on sugar cane farming cultivation area.

․ Use of McKinsey matrix for sugar production.

Technical analysis:

口 The information on material inputs and utilities with special emphasis on raw materials, processed industrial materials, auxilliary materials, factory supplies were decided.

u Also the requirement of utilities like water, power supply and fuel were analyzed with suitable assumptions.

口 The decision regarding the manufacturing process, plant capacity, location and site, machinary and equipment were made with detailed justification wherever needed.

૫ Financial analysis:

口 Details on fixed capital investment consisting of land and building, plant and machinary with detailed description, furniture and computer and pre-operative expenses were collected.

口 The financial analysis of working capital expenses, staff and labour were done separately.

口 Finally the financial analysis of other expenses like electricity, water,transportation, repairing and maintenence, insurance, advertisement and publicity, postage and stationary were done.

u Break-Even analysis was calculated to check the recovery of the initial investment.

Economic analysis :

Q The bar chart showing the Indian sugarcane prices are the highest in the world was dislayed

u Whereas on the other hand, another bar chart shows that the Indian sugar price is amongst the lowest in the world.

口 So some information was collected on how to improvise the quality of the sugar using best raw materials and best resources available.

u Some analysis was done on energy conservation, so as to economically produce the sugar.

Ecological analysis :

( Existing methods of treating effluents in sugar industries were discussed

口 Further some innovative and latest techniques for treating effluents in India and abroad were discussed with special reference to the reserach area in this sector.

口 The effluents and treatments were discussed along with the $\mathrm{pH}$ value, TDS, TSS etc and detailed conclusions were drawn.

\section{6 . Strengths of course project}

The following are the benefits found from the conduct of course project for post graduate students of production management programme.

i) The conduct of course project has helped students in clear understanding of the course (Project Management) as they could correlate their work with each of the chapters in the course.

ii) Industry visit made students to realize the importance of course (project management) in real time application.

iii) The course project forced students to think and analyze the concepts of project management, especially project facets analysis, hence there was an increase in learning level from L3 to L4 of Bloom's Taxonomy.

iv) Many financial and economic terms /concepts were introduced to the students as they worked on it during feasibility study and analysis or else they would never come across such concepts in other courses.

The course project in project management has not only helped students to be an effective and efficient project manager, but it also helped them to think and develop skills required for an entrepreneur.

\section{Conclusions}

The conduct of course project for the course - project management at post graduate level has helped students in many ways as mentioned in section 5 above. Along with this, the faculty member was also 
able to measure the attainment of "Project Management and Finance" graduate attribute (GA) as per the norms of National Board of Accreditation (NBA). The overall attainment of GA 7 increased from almost $72 \%$ to $79 \%$, with clarity in the process of conducting course project. There are two areas of improvements identified as per the results and attainment calculations.

i) Students have to focus and concentrate on feasibility study and steps involved in it during the initial phase of project management.

ii) The collection of data and interpretation should be more towards economical and ecological analysis as they are utmost important concepts of project management facet analysis.

The analysis of marketing, technical and financial factors were found to be much satisfactory. So, overall the conduct of course project for post graduate students at first semester level in the programme production management from last two academic years was satisfactorily conducted and helped both faculties and students in their respective manners.

\section{References}

[1] National Board of Accreditation Manual for PG Engineering Programs.

[2]Louis Klein, Christopher Beisenthal, Erlend Dehlin. "Improvisation in project management: A praxeology" , International journal of project management 33 (2015) 267-277

[3] S Choudhury, "Project Management", Tata McGraw-Hill Publishing Company Limited, New Delhi

[4]Prasanna Chandra, " Planning, Analysis, Selection, Implementation and Review" seventh edition , Tata McGraw-Hill Publishing Company Limited, New Delhi

[5] Course Project Reports submitted by 1st semester M.Tech Production Management students. 